\title{
Molecular survey of selected viral pathogens in wild leopard cats (Prionailurus bengalensis) in Taiwan with an emphasis on the spatial and temporal dynamics of carnivore protoparvovirus 1
}

\author{
Chen-Chih Chen ${ }^{1,6}$ (1) $\cdot$ Ai-Mei Chang ${ }^{2} \cdot$ Wan-Jhen Chen ${ }^{1} \cdot$ Po-Jen Chang ${ }^{3} \cdot$ Yu-Ching Lai ${ }^{4} \cdot$ Hsu-Hsun Lee ${ }^{5}$
}

Received: 29 February 2020 / Accepted: 19 October 2020 / Published online: 3 January 2021

(c) The Author(s), under exclusive licence to Springer-Verlag GmbH, AT part of Springer Nature 2021

\begin{abstract}
The leopard cat (Prionailurus bengalensis) was listed as an endangered species under the Wildlife Conservation Act in Taiwan in 2009. However, no study has evaluated the possible direct or indirect effects of pathogens on the Taiwanese leopard cat population. Here, we targeted viral pathogens, including carnivore protoparvovirus 1 (genus Protoparvovirus), feline leukemia virus (FeLV), feline immunodeficiency virus (FIV), coronaviruses (CoVs), and canine distemper virus (CDV), through molecular screening. The spatial and temporal dynamics of the target pathogens were evaluated. Through sequencing and phylogenetic analysis, we clarified the phylogenetic relationship of viral pathogens isolated from leopard cats and domestic carnivores. Samples from 23 live-trapped leopard cats and 29 that were found dead were collected from 2015 to 2019 in Miaoli County in northwestern Taiwan. Protoparvoviruses and CoVs were detected in leopard cats, and their prevalence (95\% confidence interval) was 63.5\% (50.4\%-76.6\%) and 8.8\% (0\%-18.4\%), respectively. Most of the protoparvovirus sequences amplified from Taiwanese leopard cats and domestic carnivores were identical. All of the CoV sequences amplified from leopard cats were identified as feline CoV. No spatial or temporal aggregation of protoparvovirus infection in leopard cats was found in the sampling area, indicating a wide distribution of protoparvoviruses in the leopard cat habitat. We consider sympatric domestic carnivores to be the probable primary reservoir for the identified pathogens. We strongly recommend management of protoparvoviruses and feline $\mathrm{CoV}$ in the leopard cat habitat, particularly vaccination programs and population control measures for free-roaming dogs and cats.
\end{abstract}

Handling Editor: Tim Skern.

Chen-Chih Chen and Ai-Mei Chang contributed equally and listed as co-first authors.

Supplementary Information The online version contains supplementary material available at https://doi.org/10.1007/s0070 5-020-04904-z.

\section{Chen-Chih Chen}

ychih0502@gmail.com

1 Institute of Wildlife Conservation, College of Veterinary Medicine, National Pingtung University of Science and Technology, Pingtung, Taiwan

2 Graduate Institute of Animal Vaccine Technology, College of Veterinary Medicine, National Pingtung University of Science and Technology, Pingtung, Taiwan

3 Formosan Wild Sound Conservation Science Center, Miaoli, Taiwan

\section{Introduction}

The leopard cat (Prionailurus bengalensis) is an endangered felid species that is distributed in East, Southeast, and South Asia [1]. It was commonly distributed in lowland habitats throughout Taiwan [2, 3]. However, after an island-wide decline in its population, in 2009, the Wildlife Conservation Act of Taiwan listed the leopard cat as an endangered species [4]. Currently, the distribution of Taiwanese leopard cats

4 Department of Landscape Architecture and Environmental Design, Huafan University, New Taipei City, Taiwan

5 Department of Veterinary Medicine, College of Veterinary Medicine, National Pingtung University of Science and Technology, Pingtung, Taiwan

6 Research Center for Animal Biologics, National Pingtung University of Science and Technology, Pingtung, Taiwan 
is restricted to small areas in three counties in central Taiwan: Miaoli, Nantou, and Taichung City. Studies in Miaoli County have suggested that road traffic, habitat fragmentation and degradation, illegal trapping, and poisoning are the principal threats to the sustainability of its population [5]. However, the possible direct or indirect effects of pathogens on Taiwanese leopard cat population have not been evaluated. Moreover, information related to infectious agents affecting the wild Taiwanese leopard cat population is scant. Our previous study documented the distribution of carnivore protoparvovirus 1 in Taiwanese leopard cats and its association with domestic carnivores [6]. To the best of our knowledge, this was the only study on infectious agents in free-living leopard cats in Taiwan. The effects of infectious diseases on the wildlife population have been increasingly recognized [7, 8]. Although conspicuous illnesses or mass die-offs of wild animals caused by specific agents are easy to identify and are usually recognized as a threat to the abundance of wildlife populations, unremarkable or sublethal diseases in wild animals, which are more difficult to identify, may reduce their fitness through an increased energy output or decreased food intake, thus substantially arresting population growth [7,9].

Pathogen infection in wild felids has been documented worldwide with different degrees of importance. The viral pathogens that have been identified in wild or captive leopard cats include feline immunodeficiency virus (FIV) [10], carnivore protoparvovirus 1 (genus Protoparvoviruses) [6, 11, 12], feline herpesvirus type 1 (FHV-1) [11], and feline calicivirus (FCV) [11]. Furthermore, bacterial and parasitic agents include Anaplasma [13, 14], hemoplasmas [13, 15], Hepatozoon felis [16-18], and several helminths [19]. Although the effects of these infectious agents on leopard cats remain unclear, identifying infectious agents in the leopard cat population is essential for disease management and species conservation.

In our previous study, we recorded protoparvovirus infection in free-living leopard cats, although that study had a limited sample size [6]. Here, we have extended the screening to include other viral pathogens and increased the sample size. The target viral pathogens were protoparvoviruses, feline leukemia virus (FeLV), FIV, coronaviruses (CoVs), and canine distemper virus (CDV). The target pathogens were identified through molecular screening, and their spatial and temporal distribution was analyzed. Furthermore, through sequencing and phylogenetic analysis, we determined the phylogenetic relationship of viral pathogens of leopard cats to those of domestic carnivores.

\section{Materials and methods}

\section{Study area}

All samples from leopard cats were collected from Miaoli County in northwestern Taiwan (Fig. 1). The landscape of the sampling area for the leopard cat population and the population of sympatric free-roaming domestic carnivores was described previously [6].

\section{Sample collection}

Samples from leopard cats were collected from January 2015 to April 2019. Free-living leopard cats were trapped for radio telemetry tracking, or for relocation if they invaded poultry farms. Permission for conducting this study was issued by the Forest Bureau (permit no.: Council of Agriculture, Forestry Bureau, 1061702029, 1081603388). Steel-mesh box traps (108-Rigid Trap, Tomahawk Live Trap, Hazelhurst, WI, USA) baited with live quails were employed for trapping leopard cats. The trapped leopard cats were anesthetized by veterinarians by using a mixture of dexmedetomidine hydrochloride (100 $\mu \mathrm{g} / \mathrm{kg}$ ) and tiletamine $\mathrm{HCl} /$ zolazepam $\mathrm{HCl}(2 \mathrm{mg} / \mathrm{kg})$. The procedures for leopard cat trapping, anesthesia administration, and sample collection were approved by the Institutional Animal Care and Use Committee of the National Pingtung University of Science and Technology (approval numbers: NPUST-106-014 and NPUST-107-041).

The carcasses of found-dead (FD) leopard cats, with most deaths caused by vehicle collisions, were collected and submitted by the County Government of Miaoli for additional necropsy and sample collection.

The types of tissues and swabs collected for PCR or reverse transcription PCR (RT-PCR) screening of selected pathogens and the corresponding primers are presented in Table 1.

We recorded the sex and age of each leopard cat. Age was estimated as described previously [6]. The samples from 2015 to 2017 used in this study were the same as those used by Chen et al. [6]

\section{Nucleic acid extraction and RT-PCR screening for selected viral pathogens}

Samples were homogenized prior to nucleic acid extraction. Total DNA was extracted from the collected tissues and blood samples using a DNeasy Blood and Tissue Kit, and total RNA was extracted using an RNeasy Mini Kit and a QIAamp RNA Blood Mini Kit (QIAGEN, Valencia, CA, USA). A QIAamp DNA Stool Mini Kit and a 


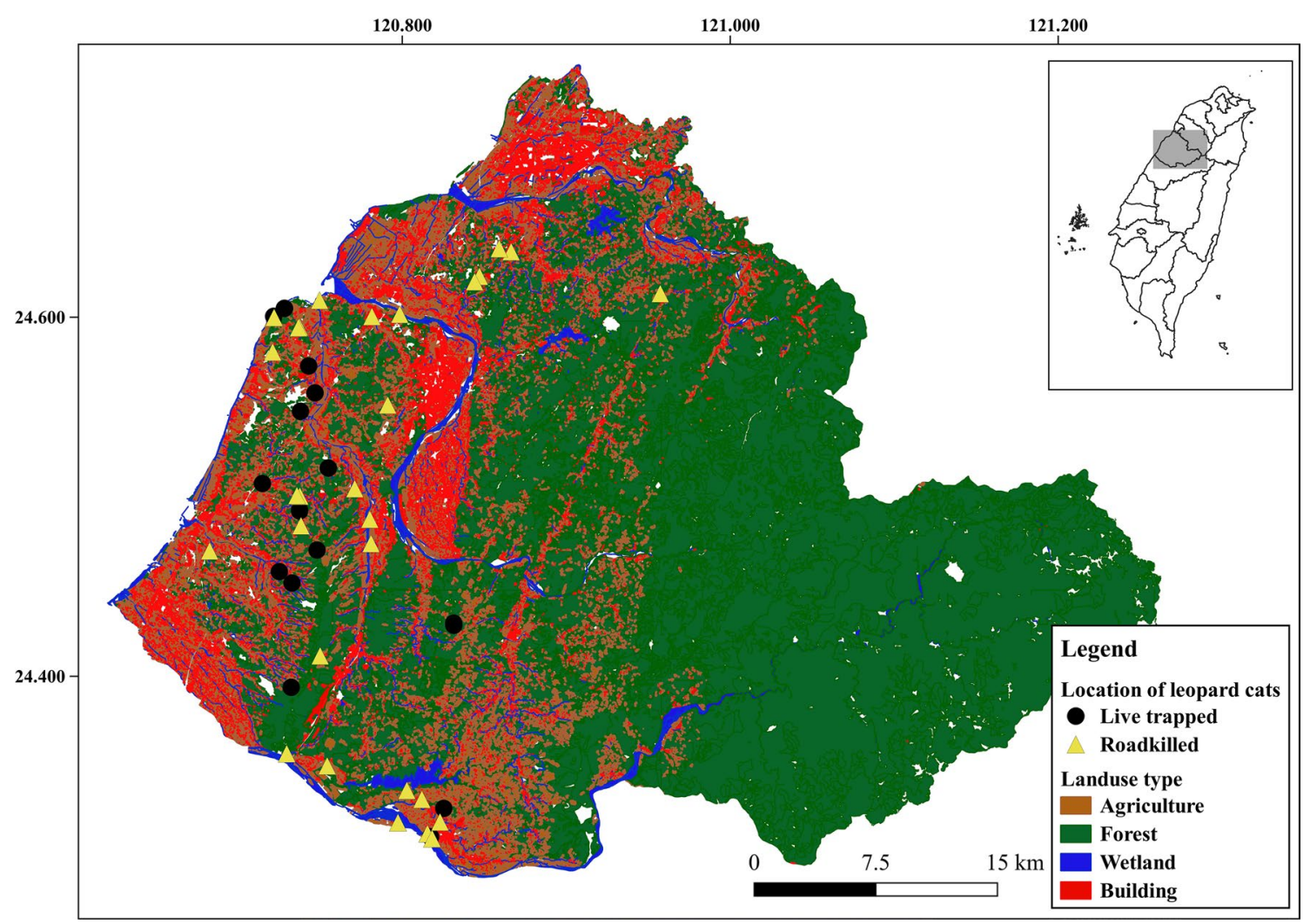

Fig. 1 Sampling sites of leopard cats in Miaoli County. The inset map of Taiwan indicates the location of Miaoli County. Circles and triangles denote leopard cats that were live-trapped and found dead, respectively. The land-use type (agriculture, forest, wetland, or building areas) is indicated in the background.

\section{QIAamp Viral RNA Mini Kit (QIAGEN) were used to} extract DNA and RNA, respectively, from rectal swabs.

The manufacturer's recommended procedures were followed for nucleic acid extraction. Reverse transcription of total RNA to cDNA was performed using an iScript cDNA Synthesis Kit (Bio-Rad, Hercules, CA, USA) following the manufacturer's instructions.

We selected consensus primer sets for each viral pathogen to avoid possible nucleotide mutations at the primer annealing sites [20]. The detection limit of RTPCR was 10-100 gene copies/ $\mu \mathrm{L}$ (Table 2). Samples that were PCR-positive for the virus were then subjected to sequencing for confirmation.

PCR amplicons were sequenced in an ABI377 sequencer using an ABI PRISM dye-terminator cycle sequencing ready reaction kit with AmpliTaq DNA polymerase (Perkin-Elmer, Applied Biosystems, MA, USA). To identify sequences similar to those of the amplicons, a BLAST search of the GenBank nt/nr database, available on the BLAST website (https://blast.ncbi.nlm.nih. gov/Blast.cgi), was performed.

\section{Phylogenetic analysis}

We selected sequences for phylogenetic analysis from the NCBI GenBank database (https://www.ncbi.nlm.nih.gov/ nucleotide/) through a BLAST search (accessed on September 10, 2020) of each amplified sequence from the leopard cat samples. The GenBank sequences were restricted to sequences amplified in our sampling area, Taiwan, and other Asian countries. Furthermore, some sequences were observed to be widely distributed in Asian countries; we retrieved five sequences of each type in Asian countries. The nucleotide sequences of the infectious agents identified in this study and those retrieved from GenBank were aligned using CLUSTALW [27] in MEGA 7 software [28]. Protoparvovirus variants were classified based on the amino acid residues of the VP2 gene at positions 300, 305, 323, and 426 [21]. For identical sequences of the same protoparvovirus variant, we added a number after the variant designation (e.g., CPV-2a/1 is strain 1 of the CPV-2a variant). The maximum-likelihood method [29] with 1000 bootstrap replicates was used to model the phylogenetic relationship of the 
Table 1 Samples collected from free-living leopard cats and PCR primers used for amplifying the target pathogens

\begin{tabular}{|c|c|c|c|c|c|c|}
\hline \multirow[t]{2}{*}{ Virus $^{1}$} & \multicolumn{2}{|l|}{ Sample for screening } & \multirow[t]{2}{*}{ Screening method } & \multirow{2}{*}{$\begin{array}{l}\text { Primer nucleotide } \\
\text { position in the viral } \\
\text { genome } \\
\text { (annealing tempera- } \\
\text { ture }{ }^{\circ} \mathrm{C} \text { ) }\end{array}$} & \multirow{2}{*}{$\begin{array}{l}\text { Amplicon size and } \\
\text { gene }\end{array}$} & \multirow[t]{2}{*}{ Ref. } \\
\hline & Live-trapped & Carcasses & & & & \\
\hline Protoparvoviruses & $\begin{array}{l}\text { Whole blood, rectal } \\
\text { swab }\end{array}$ & $\begin{array}{l}\text { spleen, } \\
\text { lymph node, } \\
\text { small intestine, } \\
\text { rectal swab }\end{array}$ & Nested PCR & $\begin{array}{l}\text { First set }\left(52^{\circ} \mathrm{C}\right): \\
\text { M10 }(3612-3637): \\
\text { 5'-ACACATACA } \\
\text { TGGCAAACA } \\
\text { AATAGA-3' } \\
\text { M11 (4125-4150): } \\
\text { 5'-ACTGGTGGT } \\
\text { ACATTATTTAAT } \\
\text { GCAG-3' } \\
\text { Second set }\left(65^{\circ} \mathrm{C}\right): \\
\text { M13 (3629-3658): } \\
\text { 5'-AATAGAGCA } \\
\text { TTGGGCTTACCA } \\
\text { CCATTTTT-3' } \\
\text { M14 (4082-4111): } \\
\text { 5'ATTCCTGTT } \\
\text { TTACCTCCAATT } \\
\text { GGATCTGTT-3' }\end{array}$ & 482 bp; VP2 gene & [21] \\
\hline FeLV & whole blood & spleen & Nested PCR & $\begin{array}{l}\text { First set }\left(50^{\circ} \mathrm{C}\right): \\
\text { U3-F1 }(186-205): \\
\text { 5'- ACAGCAGAA } \\
\text { GTTTCAAGG } \\
\text { CC-3' } \\
\text { G-R1 (936-955): } \\
\text { 5'-GACCAGTGA } \\
\text { TCAAGGGTG } \\
\text { AG-3' } \\
\text { Second set }\left(52^{\circ} \mathrm{C}\right): \\
\text { U3-F2 }(224-243): \\
\text { 5'-GCTCCCCAG } \\
\text { TTGACCAGA } \\
\text { GT-3' } \\
\text { G-R2 (824-805): } \\
\text { 5'-GCTTCGGTA } \\
\text { CCAAACCGA } \\
\text { AA-3' }\end{array}$ & $\begin{array}{l}601 \mathrm{bp} \text {; Gag and } \\
\text { LTR gene }\end{array}$ & [22] \\
\hline FIV & Whole blood & Spleen & Nested PCR & $\begin{array}{l}\text { First set }\left(52^{\circ} \mathrm{C}\right): \\
\text { P1F }(2407-2435): \\
\text { 5'-TGGCCW } \\
\text { YTAWCWAAT } \\
\text { GAAAARATW } \\
\text { GAAGC-3' } \\
\text { P2R (3401-3427): } \\
\text { 5'-GTATTYTCT } \\
\text { GCYTTTTTCTTY } \\
\text { TGTCTA-3' } \\
\text { Second set }\left(50^{\circ} \mathrm{C}\right): \\
\text { P2F (2421-2450): } \\
\text { 5'- TGAAAA } \\
\text { RATWGA } \\
\text { AGCHTTAACA } \\
\text { GAMATAG-3' } \\
\text { P1R (2967-2997): } \\
\text { 5'-GTAATTTRT } \\
\text { CTTCHGGNGTY } \\
\text { TCAAATCCCC-3' }\end{array}$ & $\begin{array}{l}576 \mathrm{bp} \text {; RNA- } \\
\text { dependent DNA } \\
\text { polymerase gene }\end{array}$ & [23] \\
\hline
\end{tabular}


Table 1 (continued)

\begin{tabular}{|c|c|c|c|c|c|c|}
\hline \multirow[t]{2}{*}{ Virus $^{1}$} & \multicolumn{2}{|c|}{ Sample for screening } & \multirow[t]{2}{*}{ Screening method } & \multirow{2}{*}{$\begin{array}{l}\text { Primer nucleotide } \\
\text { position in the viral } \\
\text { genome } \\
\text { (annealing tempera- } \\
\text { ture }{ }^{\circ} \mathrm{C} \text { ) }\end{array}$} & \multirow{2}{*}{$\begin{array}{l}\text { Amplicon size and } \\
\text { gene }\end{array}$} & \multirow[t]{2}{*}{ Ref. } \\
\hline & Live-trapped & Carcasses & & & & \\
\hline $\mathrm{CoV}$ & $\begin{array}{l}\text { Whole blood, } \\
\text { rectal swab }\end{array}$ & $\begin{array}{l}\text { Spleen, } \\
\text { Small intestine, } \\
\text { lymph node, } \\
\text { rectal swab }\end{array}$ & $\begin{array}{l}\text { RT-semi nested } \\
\text { PCR }^{2}\end{array}$ & $\begin{array}{l}\text { First set }\left(54.7^{\circ} \mathrm{C}\right): \\
\text { IN-6 }(14215-14237): \\
\text { 5'-GGTTGGGAC } \\
\text { TATCCTAAG } \\
\text { TGTGA-3' } \\
\text { Cor-RV }(14791- \\
\text { 14813): 5'-TGT } \\
\text { GAGCAAAAT } \\
\text { TCGTGAGGTCC- } \\
\text { 3' } \\
\text { Second set }\left(55^{\circ} \mathrm{C}\right): \\
\text { IN-6 }(14215-14237): \\
\text { 5'-GGTTGGGAC } \\
\text { TATCCTAAG } \\
\text { TGTGA-3' } \\
\text { IN-7 (14631-14654): } \\
\text { 5'- CCATCATCA } \\
\text { GATAGAATCATC } \\
\text { ATA-3' }\end{array}$ & $\begin{array}{l}439 \mathrm{bp} ; \text { RNA- } \\
\text { dependent DNA } \\
\text { polymerase gene }\end{array}$ & {$[24,25]$} \\
\hline CDV & Whole blood & $\begin{array}{l}\text { Spleen, lung, lymph } \\
\text { node }\end{array}$ & RT-semi nested PCR & $\begin{array}{l}\text { First set }\left(48^{\circ} \mathrm{C}\right): \\
\text { F1 }(10080-10105): \\
\text { 5'-TCITTYTTT } \\
\text { AGRASITTYG- } \\
\text { GNCAYCC-3' } \\
\text { R (10665-10690): } \\
\text { 5'-CKCATTTT } \\
\text { GTAIGTCATY } \\
\text { TTNGCRAA-3' } \\
\text { Second set }\left(55^{\circ} \mathrm{C}\right): \\
\text { F2 (10197-10225): } \\
\text { GCYATATTY } \\
\text { TGTGGRATA } \\
\text { ATHATHAAYGG } \\
\text { R (10665-10690): } \\
\text { 5'-CKCATTTT } \\
\text { GTAIGTCATY } \\
\text { TTNGCRAA-3' }\end{array}$ & $\begin{array}{l}494 \text { bp; RNA- } \\
\text { dependent RNA } \\
\text { polymerase gene }\end{array}$ & [26] \\
\hline
\end{tabular}

${ }^{1}$ protoparvoviruses, carnivore protoparvovirus 1; FeLV, feline leukemia virus; FIV, feline immunodeficiency virus; CoV, coronavirus; CDV, canine distemper virus

${ }^{2}$ RT seminested PCR, reverse transcription seminested PCR

Table 2 Sensitivity of specific PCR assays for detecting protoparvoviruses, FeLV, FIV, CoV, and CDV. The target genes were cloned into a plasmid vector, and the plasmid was diluted to $10^{\circ}$ to $10^{9}$ gene copies $/ \mu \mathrm{L}$ for each detection assay

\begin{tabular}{ll}
\hline Targeted agent & Sensitivity $($ gene copies $/ \mu \mathrm{l})$ \\
\hline Protoparvoviruses & 10 gene copies $/ \mu \mathrm{l}$ \\
FeLV & 100 gene copies $/ \mu \mathrm{l}$ \\
FIV & 10 gene copies $/ \mu \mathrm{l}$ \\
$\mathrm{CoV}$ & 100 gene copies $/ \mu \mathrm{l}$ \\
$\mathrm{CDV}$ & 10 gene copies $/ \mu \mathrm{l}$ \\
\hline
\end{tabular}

sequences for each infectious agent. For each tree, the most suitable model was determined using MEGA 7 based on the lowest Bayesian information criterion (BIC) score [30].

\section{Data analysis}

Because we did not use a probability sampling design for sample collection, we estimated the prevalence of convenience samples (hereafter "prevalence") of each targeted infectious agent and the $95 \%$ confidence interval (CI) [31]. As leopard cats are endangered and our sample size was limited, 
we did not conclude that one of the targeted infectious agents was absent in the population of leopard cats if all of the individual samples tested negative.

The samples from live-trapped (LT) and FD leopard cats were pooled to identify possible spatial or temporal clusters of target pathogens using SaTScan v9 [32] with the Bernoulli model [33]. The analysis was used to determine whether positive cases were randomly distributed over space and time. Detection of a significant cluster of positive cases would help to identify the possible influencing factors, which would be critical for implementing disease management and prevention programs. Cluster determination was performed by gradually scanning a window across time and/or space and comparing the numbers of observed and expected cases [34]. Multiple window sizes were used during scanning. Significant spatial and temporal clusters were reevaluated using Monte Carlo replications under the null hypothesis to ensure adequate power for defining clusters [34]. The maximumlikelihood approach was used to determine the clusters, and a $p$-value was determined for each cluster [34].

\section{Results}

\section{Leopard cat sample collection and distribution in Miaoli County}

From 2015 to 2019, we collected samples from 23 LT and 29 FD leopard cats (Table 3; Table S1). No significant difference in sex was noted between LT and FD individuals (Pearson's chi-squared test; $p=0.157$ ). However, the FD group had significantly more adults than the LT group (Fisher's exact test; $p=0.0026$ ). Samples were collected from leopard cats across western Miaoli County in a landscape of fragmented secondary forest habitat surrounded by farmland and residential areas (Fig. 1), corresponding to the current distribution of the leopard cat population.

\section{Prevalence of convenience samples and distribution of targeted viral pathogens}

Among the targeted viral pathogens, only protoparvoviruses [prevalence $(95 \% \mathrm{CI}): 63.5 \%(50.4 \%-76.6 \%)$ ] and $\mathrm{CoV}$ [8.8\% (0\%-18.4\%)] were detected in the collected samples from leopard cats (Table 4). The prevalence of protoparvoviruses in FD cats was significantly higher than that in LT cats (Fisher's exact test, $p=0.002$ ). Furthermore, the prevalence was significantly higher in adults than in subadults (Fisher's exact test, $p=0.01$ ). No differences in prevalence were noted regarding the type of sample, sex, or age for CoV (Table 4).

The distribution of protoparvovirus-positive individuals was scattered in western Miaoli County. Three CoV-positive samples were found in northwest Miaoli (Fig. 2). No spatial or temporal aggregation of protoparvovirus infection was observed in the sampling area (SaTScan, Bernoulli model, $p$ $=0.094)$. Spatial and temporal analyses were not performed
Table 3 Sex and age distribution of live-trapped and found-dead leopard cats

\begin{tabular}{|c|c|c|c|c|c|c|c|}
\hline \multirow[t]{2}{*}{ Type of animal analyzed } & \multicolumn{3}{|c|}{ Female $(n=19)$} & \multicolumn{3}{|c|}{ Male $(\mathrm{n}=33)$} & \multirow[t]{2}{*}{ Total } \\
\hline & Adult & Subadult & Juvenile & Adult & Subadult & Juvenile & \\
\hline Live-trapped & 3 & 4 & 4 & 5 & 7 & 0 & 23 \\
\hline Found dead & 7 & 1 & 0 & 16 & 4 & 1 & 29 \\
\hline Total & 10 & 5 & 4 & 21 & 11 & 1 & 52 \\
\hline
\end{tabular}

Table 4 Prevalence of protoparvoviruses and coronaviruses in the freeliving leopard cat population according to sample type, sex, and age

\begin{tabular}{|c|c|c|c|c|}
\hline \multirow[t]{2}{*}{ Category } & \multicolumn{2}{|c|}{ Protoparvoviruses $(\mathrm{n}=52)$} & \multicolumn{2}{|c|}{ Coronaviruses $(\mathrm{n}=34)$} \\
\hline & Positive & Prevalence $(95 \%$ CI $)$ & Positive & Prevalence $(95 \% \mathrm{CI})$ \\
\hline Total & 33 & $63.5 \%(50.4-76.5)$ & 3 & $8.8 \%(0-18.4)$ \\
\hline \multicolumn{5}{|c|}{ Type of sample } \\
\hline Live-trapped & 9 & $39.1 \%(19.2-59.1)$ & 1 & $7.1 \%(0-20.6)$ \\
\hline Found-dead & 24 & $82.8 \%(69.0-96.5)$ & 2 & $10.0 \%(0-23.1)$ \\
\hline \multicolumn{5}{|l|}{ Sex } \\
\hline Female & 11 & $57.9 \%(35.7-80.1)$ & 3 & $27.3 \%(0-53.6)$ \\
\hline Male & 22 & $66.77 \%(50.6-82.8)$ & 1 & $4.3 \%(0-12.7)$ \\
\hline \multicolumn{5}{|l|}{ Age } \\
\hline Adult & 24 & $77.4 \%(62.7-92.1)$ & 0 & $0 \%(0-15)$ \\
\hline Subadult & 6 & $37.5 \%(13.8-61.2)$ & 2 & $22.2 \%(0-49.4)$ \\
\hline Juvenile & 3 & $60 \%(17-100)$ & 1 & $20 \%(0-55.1)$ \\
\hline
\end{tabular}




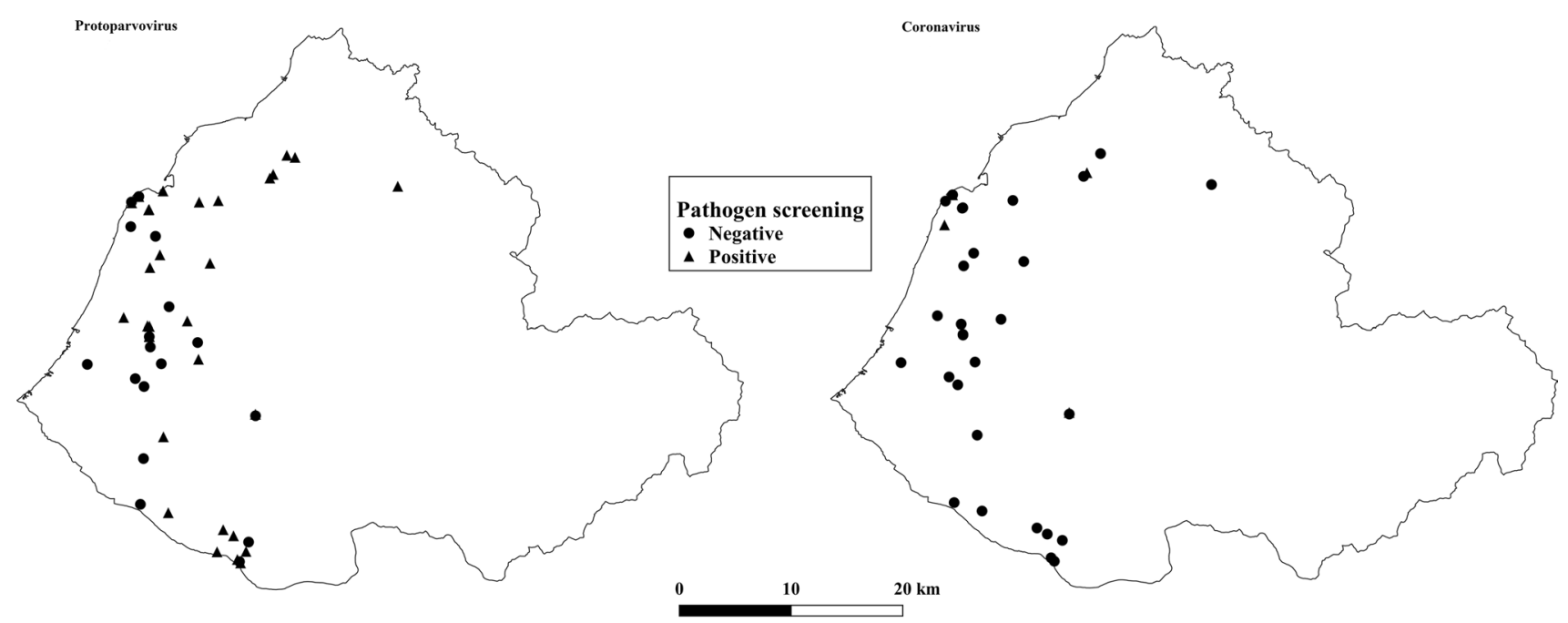

Fig. 2 Spatial distribution of protoparvoviruses and coronavirus in leopard cats. No significant aggregation of positive samples was noted for either virus.

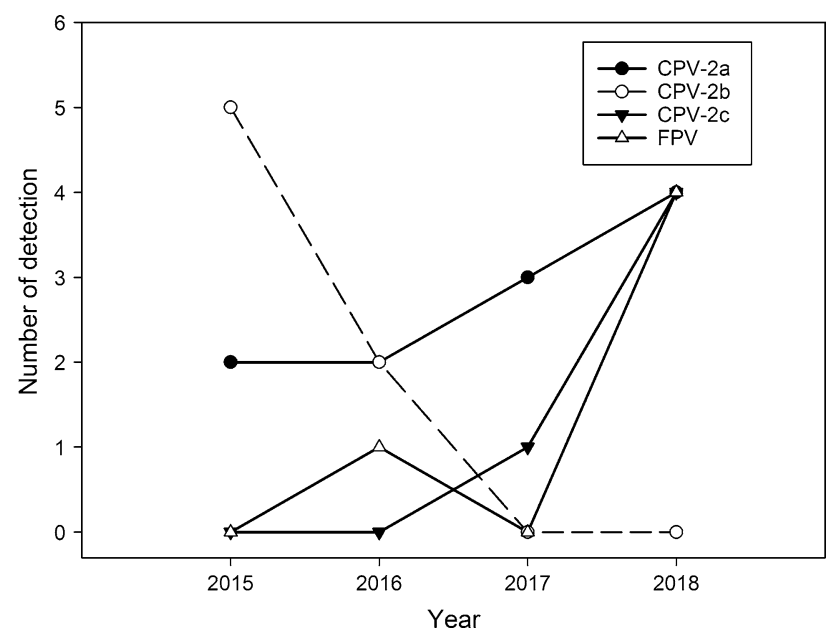

Fig. 3 Frequency of positive detection of protoparvovirus variants from 2015 to 2018

for CoV, CDV, FeLV, and FIV because there were few or no positive samples.

\section{Identification of viral variants and phylogenetic analysis}

Identification of protoparvovirus variants was based on the VP2 amino acid sequences obtained from 29 protoparvovirus-positive samples, 13 of which were from our previous study and were already in the GenBank database [6]. We determined that $11,7,6$, and 5 leopard cats were infected with CPV-2a, CPV-2b, CPV-2c, and feline panleukopenia virus (FPV), respectively (Table S2). The occurrence of protoparvovirus variants was significantly different between 2015 and 2018 (Fisher's exact test, $p=0.006$ ); the occurrence of CPV-2b decreased, and that of CPV-2c and FPV increased (Fig. 3).

Partial VP2 sequences of $414 \mathrm{bp}$ from nucleotide positions 3679 to 4092 of all protoparvovirus strains amplified from 29 leopard cats, 27 dogs, and 9 cats in Miaoli County and accessed from GenBank were included in our phylogenetic analysis (Table S3). We adopted the Tamura 3-parameter model to construct a protoparvovirus phylogenetic tree based on the lowest BIC scores. Most of the sequences of each protoparvovirus variant from leopard cats and domestic carnivores in Taiwan were identical, comprising strains CPV-2a/1, CPV-2b/1, CPV-2b/3, CPV2c/1, CPV-2c/2, and FPV-1 (Fig. 4, Table S3). However, certain strains were detected in leopard cats but not in domestic carnivores (Fig. 4, Table S3). Most nucleotide mutations in different protoparvovirus variants from leopard cats were synonymous (Fig. 4; Table S2), whereas nonsynonymous mutations were found in CPV-2a/3, with P352L and P356S substitutions; CPV-2b/2, with an S339N substitution; FPV/2, with an A379V substitution; and FPV/3, with Q310L, A334T, R377K, and R382K substitutions.

Phylogenetic analysis of the three sequences (length: $381 \mathrm{bp}$, positions 14,218 to 14,598 ) amplified from the RNA-dependent DNA polymerase (RdRP) gene of CoV from leopard cats was performed using the Tamura threeparameter model with a discrete gamma distribution. The phylogenetic tree indicated that all of the $\mathrm{CoV}$ sequences from leopard cats belonged to a cluster corresponding to the species Alphacoronavirus 1 and a feline coronavirus subcluster (Fig. 5). 


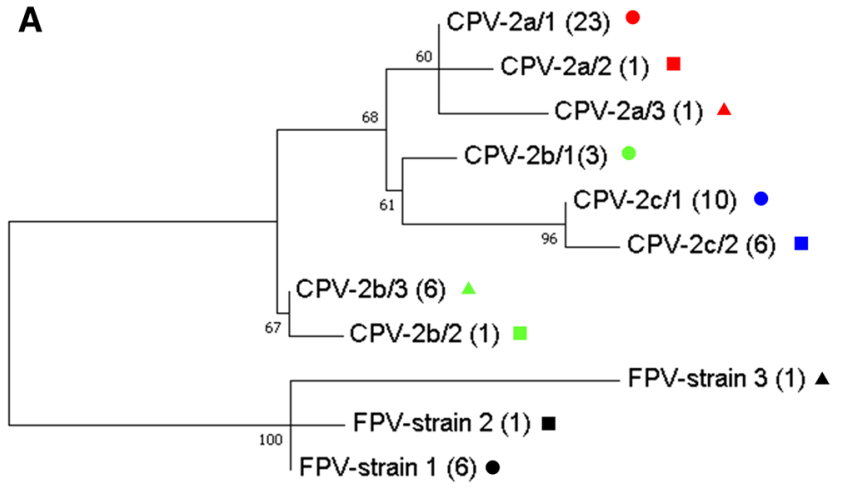

B

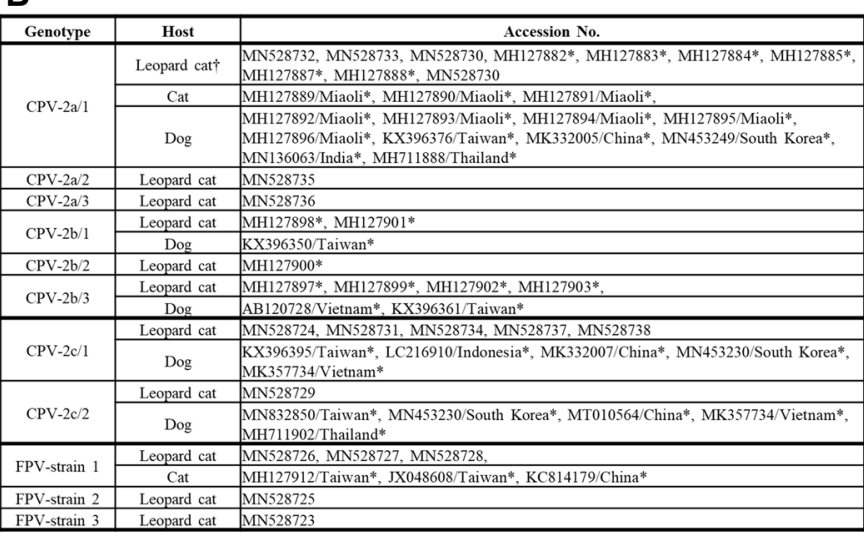

*Sequence retrieved from Genbank

†All the leopard cat samples were collected from Miaoli-Taiwan

Fig. 4 Molecular phylogenetic relationship of partial VP2 sequences of carnivore protoparvovirus 1 amplified from leopard cats and domestic carnivores and sequences retrieved from GenBank. A, phylogenetic tree; $\mathbf{B}$, information about strains, host and isolation area/ country of each sequence amplified or retrieved from GenBank; C, spatial distribution of strains amplified in this study or retrieved from

\section{Discussion}

In this study, we screened for selected viral pathogens using RT-PCR and determined the distribution of protoparvoviruses and CoVs in free-living leopard cats. Phylogenetic analysis revealed that, in most cases, identical strains of protoparvovirus variants were present both in leopard cats and in domestic carnivores; however, unique strains were also identified in leopard cats. RdRp sequencing revealed that all the CoVs identified were strains of feline $\mathrm{CoV}$ (FCoV), species Alphacoronavirus 1.

Protoparvovirus and FCoV infection in free-living leopard cats has been reported only in Taiwan [6], although protoparvovirus infection has been reported previously in captive leopard cats in Taiwan and Vietnam $[11,12]$. The worldwide distribution of protoparvoviruses has resulted in the infection of various wild carnivorous species [21,

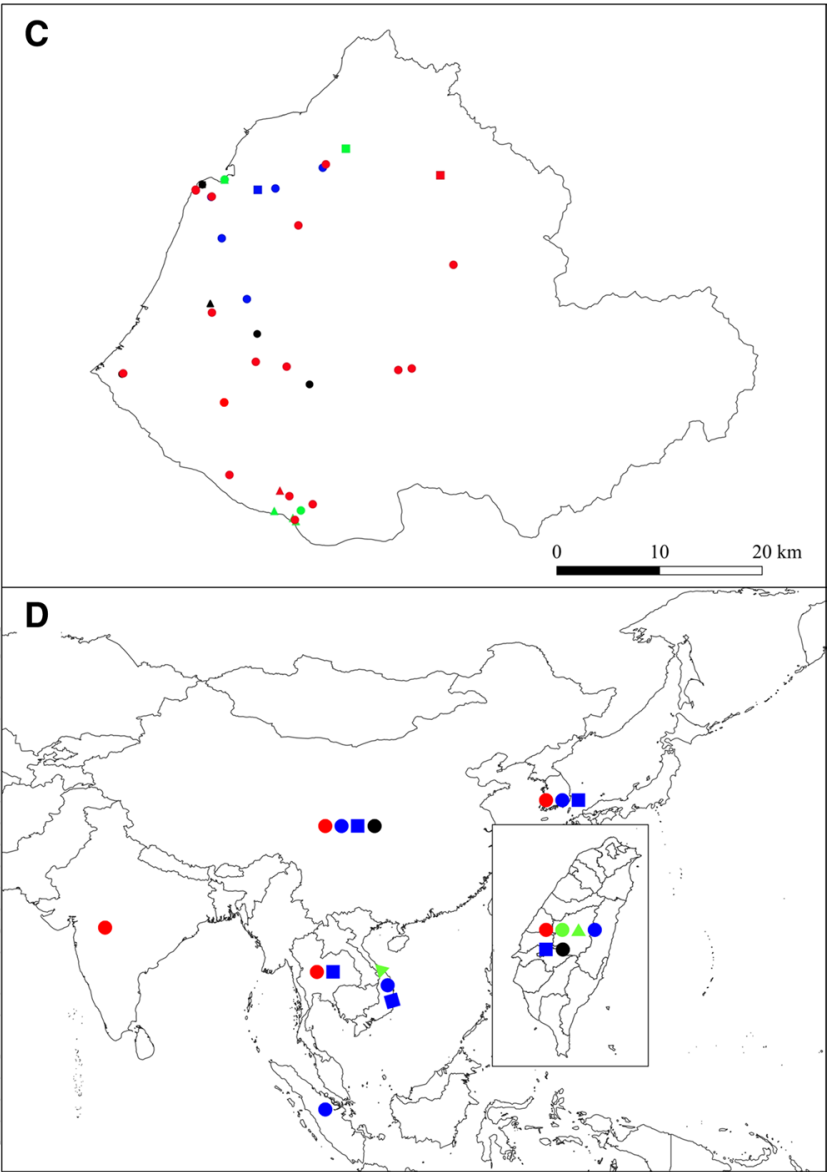

GenBank in the sampling area; D, spatial distribution of each strain retrieved from GenBank in Taiwan and Southeast Asia. The bootstrap value is reported next to the node with 1000 replicates. Each variant and strain is labeled and followed by the number of identical sequences within each group (e.g., CPV-2a/1 (23) indicates that strain 1 of the CPV-2a variant contains 23 identical sequences)

35-38]. Mech et al. [38] determined that protoparvoviruses reduced wolf pup survival by $40 \%-60 \%$ and impeded their population growth rate. Although clinical signs of protoparvovirus infection are commonly found in juvenile or subadult individuals of domestic carnivores, severe clinical signs of protoparvovirus infection have also been noted in adults [39-41]. Studies have been increasingly reporting severe protoparvoviruses enteritis in adult dogs [40, 42]. Furthermore, a higher risk of chronic gastrointestinal disease in dogs after protoparvovirus infection has been reported [43]. In our study, we observed a higher prevalence of protoparvoviruses in FD samples and adults. A higher prevalence may represent a higher risk of infection or lower mortality. However, prevalence data alone are insufficient to evaluate the effect of protoparvoviruses on different sample types or age categories. Therefore, information regarding the physical effects, pathological 


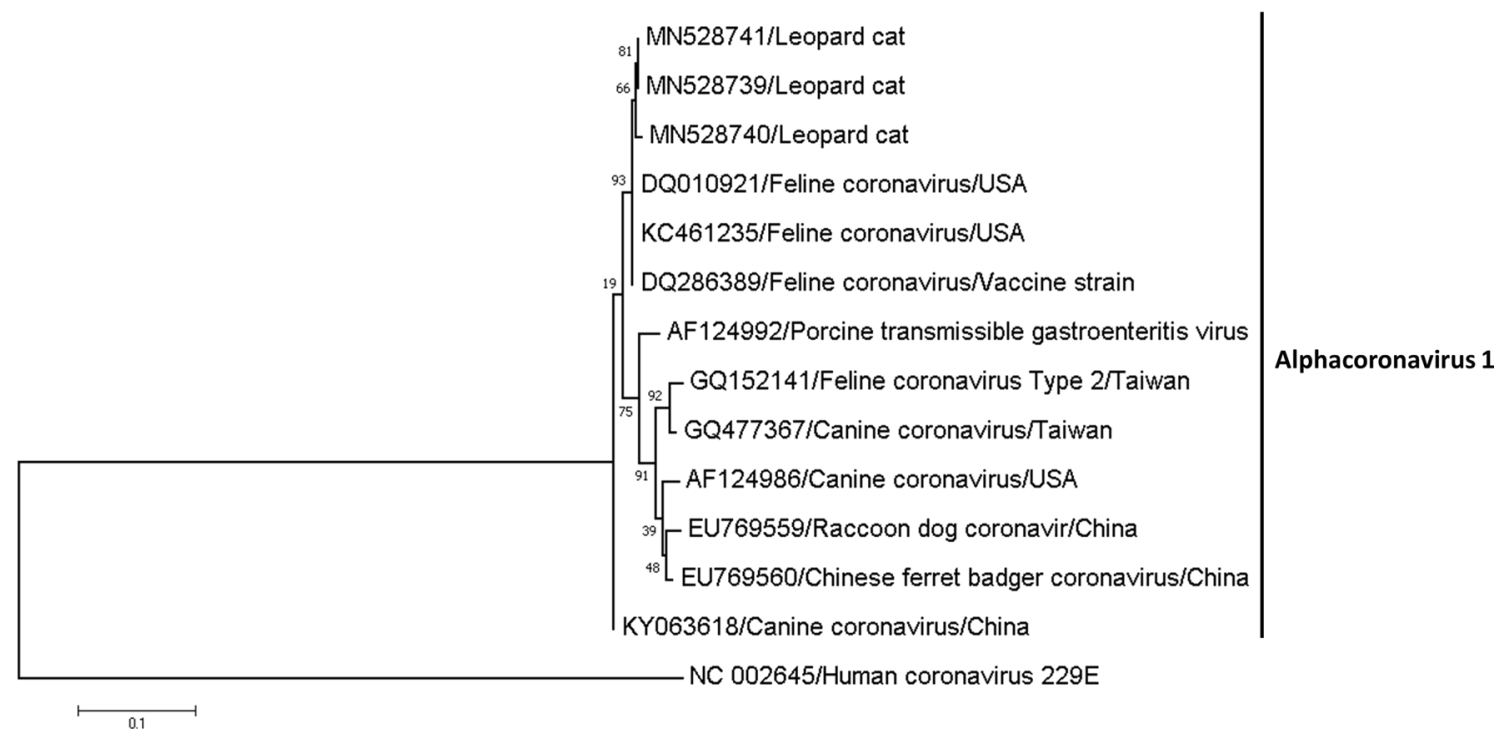

Fig. 5 Molecular phylogenetic relationship of the partial RNAdependent RNA polymerase gene of coronavirus amplified from leopard cats and sequences retrieved from GenBank. The bootstrap

changes, and mortality caused by protoparvoviruses is required.

FCoV infection has been documented in various domestic and wild felids [44-47]. The infection can be asymptomatic or associated with a fatal systematic disease, feline infectious peritonitis (FIP), and enteric disease [48, 49]. Mochizuki et al. [50] tested 17 Iriomote cats ( $P$. bengalensis iriomotensis, a subspecies of leopard cat) for serum antibodies against $\mathrm{FCoV}$ and found a prevalence of $82 \%$. That study indicated frequent exposure to and transmission of $\mathrm{FCoV}$ in leopard cats. Although FCoV is commonly detected in wild felids worldwide, only a few species, such as cheetahs (Acinonyx jubatus), have been reported to exhibit FIP [44, 46, 48]. In our study, two of three positive samples were from FD cats and one was from an LT cat. We did not detect any pathological changes or clinical signs related to FCoV. Nevertheless, felids infected with $\mathrm{FCoV}$ without any evidence of disease are considered chronic carriers that may increase other felids' risk of contracting FIP [45, 49].

We did not evaluate the effects of protoparvoviruses or FCoV on individuals or the population of these leopard cats. However, based on the documented effects and cases of protoparvoviruses and $\mathrm{FCoV}$ in wild felids, the effect of protoparvoviruses and $\mathrm{FCoV}$ on leopard cats should not be overlooked, and continuous surveillance is required.

No spatial aggregation of protoparvovirus infection in leopard cats was found in the sampling area, which indicated an even distribution of protoparvoviruses in the leopard cat habitat, and the probability of exposure to protoparvoviruses was similar throughout the population of leopard cats in the sampling area. However, our sample value for 1000 replicates is reported next to the node. Three amplified sequences for leopard cats (GenBank accession numbers: MN528739 - MN528741) are located in the feline coronavirus cluster.

size was only 52 , and the sampling design was not random. The total population of leopard cats was estimated to be 354-524 individuals [51], and our sampling area was approximately half of their critical habitat area in Taiwan. We believed that the sample size covered a relatively high proportion of the population and that the sample was representative of the population. Protoparvoviruses are stable in the environment, and can remain infectious for several months [35]. Free-roaming domestic carnivores are commonly observed in the sampling area, which is an active area with well-developed road systems [52, 53]. Although the sample size was small, we found a very high prevalence of protoparvoviruses ( $90 \% ; n=10$; data not shown) in free-roaming dogs and cats in our sampling area. These conditions aggravate the transmission and distribution of protoparvoviruses in the leopard cat habitat. Future studies should evaluate the influence of domestic carnivores on protoparvovirus transmission in the habitat.

In addition to pathogen surveillance, molecular analysis techniques may be useful for investigating several aspects of pathogenesis [54], including pathogen characteristics and pathogen transmission [54]. We identified infections with four variants of protoparvoviruses and $\mathrm{FCoV}$ in leopard cats by sequencing amplicons obtained by PCR or RT-PCR. A study using temporal dynamics revealed that CPV-2c and FPV infections increased and that CPV-2b gradually became the predominant protoparvovirus variant in dogs [55]. We first detected CPV-2c in leopard cats in 2017, suggesting that the original direction of transmission of protoparvoviruses might have been from domestic carnivores to leopard cats. Background information and surveillance data for FPV are 
scant. Therefore, factors that increase FPV infection rates need to be assessed.

In our previous study, partial VP2 gene sequences revealed that most sequences of protoparvovirus variants were identical between domestic carnivores and leopard cats [6], suggesting frequent transmission of protoparvoviruses between domestic and wild carnivores. In this study, we collected twice the number of leopard cat samples and identified several different strains of each protoparvovirus variant circulating in the leopard cat population (Fig. 4). However, the majority of the domestic carnivores and leopard cats were infected with a specific strain of each variant. These results support the assumption that protoparvoviruses are transmitted between domestic carnivores and leopard cats. However, the lack of complete VP2 sequences precluded the determination of the phylogenetic relationships between the protoparvoviruses isolated from leopard cats and those from domestic carnivores.

We identified nonsynonymous mutations in the strain from leopard cats. The functional importance of these amino acid substitutions is not known. The amplified DNA sequence of protoparvovirus VP2 encoded amino acids 300 to 437 (Table S2), located in the GH loop, an externally exposed loop in the antigenic region with the greatest variability [56]. Although specific protoparvovirus strains were detected in leopard cats, only a few sequences from domestic carnivores in the sampling area were available for phylogenetic analysis. Therefore, we could not determine if those strains are specific to leopard cats.

Cross-species transmission of protoparvoviruses between domestic and free-living carnivores has been demonstrated or suspected in several countries [35, 36]. Because leopard cats are endangered in Taiwan, sustained protoparvovirus transmission in this low-density population is improbable [57]. We therefore consider domestic carnivores to $\mathrm{g} 3$ the primary reservoirs because, among the carnivores in the study area, dogs and cats were the most abundant and exhibited a high prevalence of protoparvovirus infection.

In this study, we did not detect any FIV, FeLV, or CDV infections in leopard cats. The 95\% CI of FIV, FeLV, and CDV prevalence was $0 \%-5.9 \%, 0 \%-6 \%$, and $0 \%-6.3 \%$, respectively. Because FIV and FeLV proviral DNA gets incorporated in peripheral blood monocytic cells of felids, which can be long-term carriers of the virus, the probability of a false negative by PCR screening is low. Therefore, we consider the prevalence of FIV and FeLV to be low in Taiwanese leopard cats. Serological surveys of FIV and FeLV in leopard cats in Taiwan and Vietnam revealed no positive cases [12, 58]. However, Hayama et al. [10] determined prevalence rates of $3 \%(n=86)$ and $13.6 \%(n=280)$ for FIV infection in Tsushima leopard cats and domestic cats, respectively, in Kami-Shima, Tsushima Island, Japan. Domestic cats were considered the reservoirs of FIV in the
Tsushima case [10, 59]. The prevalence of FIV and FeLV varies among different felids and in different geographic regions [60].

CDV infection has been reported in both wild and domestic felids [60, 61]. Ikeda et al. [62] reported the detection of antibodies against CDV in a captive leopard cat in Taiwan. Furthermore, a serological survey for CDV found a prevalence of $77.8 \%$ in wild Taiwanese leopard cats [63]. Exposure to CDV in Taiwanese leopard cats is considered high. However, none of the leopard cats in our sample showed clinical signs of CDV. Although we targeted our nucleotide sequence amplification to a CDV strain found in leopard cats, a low detection rate was expected because the virus has a short shedding period. Furthermore, a diseased individual may reduce its activity, thereby reducing the likelihood that it will be found for sampling.

Our study revealed protoparvovirus and FCoV infection in free-living leopard cats. Sympatric domestic carnivores are considered the primary reservoirs for the pathogens identified in our study. Although we did not evaluate the effects of protoparvoviruses and $\mathrm{FCoV}$ on individual leopard cats or populations of leopard cats, we strongly recommend that protoparvoviruses and $\mathrm{FCoV}$ be managed in the leopard cat habitat, with an emphasis on vaccination programs and population control measures for free-roaming dogs and cats. Because of antigenic differences among protoparvovirus variants, new vaccines that also provide protection against the CPV-2c variant may need to be developed [40, 64].

Acknowledgements This study was supported by a grant from the Ministry of Science and Technology (MOST) (108-2313-B-020-001) to CC Chen. We thank the field crew members, especially Dr. Esther van der Meer, for their assistance in sample collection. This manuscript was edited by Wallace Academic Editing.

Funding This study was funded by the Ministry of Science and Technology (MOST), Taiwan (108-2313-B-020-001).

\section{Compliance with ethical standards}

Conflict of interest The authors declare that they have no conflict of interest.

Ethical approval All applicable international, national, and/or institutional guidelines for the care and use of animals were followed.

\section{References}

1. Ross J, Brodie J, Cheyne S, Hearn A, Izawa M, Loken B, Lynam A, McCarthy J, Mukherjee S, Phan C, Rasphone A, Wilting A (2015) Prionailurus bengalensis. The IUCN Red List of Threatened Species

2. Chen JS (1956) A synopsis of the Vertebrates of Taiwan. Kaimin Press, Taipei 
3. Horikawa Y (1931) A Monograph of the mammals of Formosa. Zoological Society of Formosa, Taiwan

4. Forest Bureau, Council of Agriculture, Executive Yuan (2014) Schedule of protected wildlife. Forest Bureau, Council of Agriculture, Executive Yuan, Taipei, Taiwan

5. Chen M-T, Liang Y-J, Kuo C-C, Pei KJ-C (2016) Home ranges, movements and activity patterns of leopard cats (Prionailurus bengalensis) and threats to them in Taiwan. Mammal Study 41:77-86

6. Chen C-C, Chang A-M, Wada T, Chen M-T, Tu Y-S (2019) Distribution of Carnivore protoparvovirus 1 in free-living leopard cats (Prionailurus bengalensis chinensis) and its association with domestic carnivores in Taiwan. PLoS ONE 14:e0221990

7. Wobeser GA (2006) Essentials of disease in wild animals. Blackwell Publishing, Iowa

8. Daszak P, Cunningham AA, Hyatt AD (2000) Emerging infectious diseases of wildlife-threats to biodiversity and human health. Science 287:443-449

9. Delahay RJ, Speakman JR, Moss R (1995) The energetic consequences of parasitism: effects of a developing infection of Trichostrongylus tenuis (Nematoda) on red grouse (Lagopus lagopus scoticus) energy balance, body weight and condition. Parasitology 110:473-482

10. Hayama S, Yamamoto H, Nakanishi S, Hiyama T, Murayama A, Mori H, Sugitani A, Fujiwara S-i (2010) Risk analysis of feline immunodeficiency virus infection in Tsushima leopard cats (Prionailurus bengalensis euptilurus) and domestic cats using a geographic information system. J Vet Med Sci 72:1113-1118

11. Nakamura K, Ikeda Y, Miyazawa T, Nguyen NTP, Duong DD, Le KH, Vo SD, Phan LV, Mikami T, Takahashi E (1999) Comparison of prevalence of feline herpesvirus type 1, calicivirus and parvovirus infections in domestic and leopard cats in Vietnam. J Vet Med Sci 61:1313-1315

12. Ikeda Y, Miyazawa T, Nakamura K, Naito R, Inoshima Y, Tung K-C, Lee W-M, Chen M-C, Kuo T-F, Lin JA (1999) Serosurvey for selected virus infections of wild carnivores in Taiwan and Vietnam. J Wildl Dis 35:578-581

13. Hwang J, Oh D-H, Lee H, Chun M-S (2015) Anaplasma sp. and hemoplasma infection in leopard cats (Prionailurus bengalensis euptilurus) from Korea. J Vet Sci 16:385-388

14. Tateno M, Nishio T, Sakuma M, Nakanishi N, Izawa M, Asari Y, Okamura M, Maruyama S, Miyama TS, Setoguchi A (2013) Molecular epidemiologic survey of Bartonella, Ehrlichia, and Anaplasma infections in Japanese Iriomote and Tsushima leopard cats. J Wildl Dis 49:646-652

15. Hirata M, Tateno M, Sakuma M, Nakanishi N, Izawa M, Asari Y, Okamura M, Miyama TS, Setoguchi A, Endo Y (2012) An epidemiological survey of hemoplasma infection in Iriomote cats (Prionailurus bengalensis iriomotensis). J Vet Med Sci 74:1531-1537

16. Kubo M, Miyoshi N, Yasuda N (2006) Hepatozoonosis in two species of Japanese wild cat. J Vet Med Sci 68:833-837

17. Sakuma M, Nishio T, Nakanishi N, Izawa M, Asari Y, Okamura M, Miyama TS, Setoguchi A, Endo Y (2011) A case of Iriomote cat (Prionailurus bengalensis iriomotensis) with Hepatozoon felis parasitemia. J Vet Med Sci 73:1381-1384

18. Tateno M, Nishio T, Matsuo T, Sakuma M, Nakanishi N, Izawa M, Asari Y, Okamura M, Miyama TS, Setoguchi A (2013) Epidemiological survey of tick-borne protozoal infection in iriomote cats and tsushima leopard cats in Japan. J Vet Med Sci 75:985-989

19. Yasuda N, Ezaki K, Akuzawa M, Izawa M, Doi T, Sakaguchi N, Tatara M (1994) Helminth survey of wildcats in Japan. J Vet Med Sci 56:1069-1073

20. Anthony SJ, Epstein JH, Murray KA, Navarrete-Macias I, Zambrana-Torrelio CM, Solovyov A, Ojeda-Flores R, Arrigo NC, Islam A, Khan SA (2013) A strategy to estimate unknown viral diversity in mammals. MBio 4:e00598-e1513
21. Steinel A, Munson L, Van Vuuren M, Truyen U (2000) Genetic characterization of feline parvovirus sequences from various carnivores. J Gen Virol 81:345-350

22. Miyazawa T, Jarrett O (1997) Feline leukaemia virus proviral DNA detected by polymerase chain reaction in antigenaemic but non-viraemic ('discordant') cats. Arch Virol 142:323-332

23. Adams HR, Mv V, Bosman AM, Kania S, Kennedy MA (2011) Detection and genetic analysis of feline immunodeficiency virus (FIVple) in southern African lions (Panthera leo). S Afr J Wildl Res 41:173-180

24. Poon LLM, Chu DKW, Chan KH, Wong OK, Ellis TM, Leung YHC, Lau SKP, Woo PCY, Suen KY, Yuen KY, Guan Y, Peiris JSM (2005) Identification of a Novel Coronavirus in Bats. J Virol 79:2001-2009

25. Vijgen L, Moës E, Keyaerts E, Li S, Van Ranst M (2008) A Pancoronavirus RT-PCR Assay for Detection of All Known Coronaviruses. In: Cavanagh D (ed) SARS- and Other Coronaviruses: Laboratory Protocols. Humana Press, Totowa, pp 3-12

26. Tong S, Chern S-WW, Li Y, Pallansch MA, Anderson LJ (2008) Sensitive and broadly reactive reverse transcription-PCR assays to detect novel paramyxoviruses. J Clin Microbiol 46:2652-2658

27. Thompson JD, Higgins DG, Gibson TJ (1994) CLUSTAL W: improving the sensitivity of progressive multiple sequence alignment through sequence weighting, position-specific gap penalties and weight matrix choice. Nucleic Acids Res 22:4673-4680

28. Tamura K, Stecher G, Peterson D, Filipski A, Kumar S (2013) MEGA6: molecular evolutionary genetics analysis version 6.0. Mol Biol Evol 30:2725-2729

29. Nei M, Kumar S (2000) Molecular evolution and phylogenetics. Oxford University Press, Oxford

30. Tamura K, Peterson D, Peterson N, Stecher G, Nei M, Kumar S (2011) MEGA5: molecular evolutionary genetics analysis using maximum likelihood, evolutionary distance, and maximum parsimony methods. Mol Biol Evol 28:2731-2739

31. Hanley JA, Lippman-Hand A (1983) If nothing goes wrong, is everything all right? interpreting zero numerators. J Am Med Assoc 249:1743-1745

32. Kulldorff M (2014) SaTScan ${ }^{\mathrm{TM}}$ v9. 3: Software for the spatial and space-time scan statistics. Information Management Services, Inc.

33. Kulldorff M (1997) A spatial scan statistic. Commun Stat-Theory Methods 26:1481-1496

34. Kulldorff M (2010) SaTScan user guide for version 9.0

35. Duarte MD, Henriques AM, Barros SC, Fagulha T, Mendonça P, Carvalho P, Monteiro M, Fevereiro M, Basto MP, Rosalino LM, Barros T, Bandeira V, Fonseca C, Cunha MV (2013) Snapshot of viral infections in wild carnivores reveals ubiquity of parvovirus and susceptibility of Egyptian mongoose to feline panleukopenia virus. PLoS ONE 8:e59399

36. Allison AB, Kohler DJ, Fox KA, Brown JD, Gerhold RW, ShearnBochsler VI, Dubovi EJ, Parrish CR, Holmes EC (2013) Frequent cross-species transmission of parvoviruses among diverse carnivore hosts. J Virol 87:2342-2347

37. Filipov C, Desario C, Patouchas O, Eftimov P, Gruichev G, Manov V, Filipov G, Buonavoglia C, Decaro N (2016) A ten-year molecular survey on parvoviruses infecting carnivores in Bulgaria. Transbound Emerg Dis 63:460-464

38. Mech LD, Goyal SM, Paul WJ, Newton WE (2008) Demographic effects of canine parvovirus on a free-ranging wolf population over 30 years. J Wildl Dis 44:824-836

39. Cavalli A, Bozzo G, Decaro N, Tinelli A, Aliberti A, Buonavoglia D (2001) Characterization of a canine parvovirus strain isolated from an adult dog. New Microbiol 24:239-242

40. Decaro N, Desario C, Elia G, Martella V, Mari V, Lavazza A, Nardi M, Buonavoglia C (2008) Evidence for immunisation failure in vaccinated adult dogs infected with canine parvovirus type 2c. Microbiologica 31:125-130 
41. Mochizuki M, Horiuchi M, Hiragi H, San Gabriel MC, Yasuda $\mathrm{N}$, Uno $\mathrm{T}$ (1996) Isolation of canine parvovirus from a cat manifesting clinical signs of feline panleukopenia. J Clin Microbiol 34:2101-2105

42. Decaro N, Cirone F, Desario C, Elia G, Lorusso E, Colaianni M, Martella V, Buonavoglia C (2009) Severe parvovirus in a 12-yearold dog that had been repeatedly vaccinated. Vet Rec 164:593-595

43. Kilian E, Suchodolski JS, Hartmann K, Mueller RS, Wess G, Unterer S (2018) Long-term effects of canine parvovirus infection in dogs. PLoS ONE 13:e0192198

44. Juan-Sallés C, Domingo M, Herráez P, Fernández A, Segalés J, Fernández J (1998) Feline infectious peritonitis in servals (Felis serval). Vet Rec 143:535-535

45. Kennedy M, Citino S, McNabb AH, Moffatt AS, Gertz K, Kania $S$ (2002) Detection of feline coronavirus in captive Felidae in the USA. J Vet Diagn Investig 14:520-522

46. Kennedy M, Kania S, Stylianides E, Bertschinger H, Keet D, van Vuuren M (2003) Detection of feline coronavirus infection in southern African nondomestic felids. J Wildl Dis 39:529-535

47. Van Rensburg IBJ, Silkstone MA (1984) Concomitant feline infectious peritonitis and toxoplasmosis in a cheetah (Acinonyx jubatus). J S Afr Vet Assoc 55:205-207

48. Evermann JF, Benfield DA (2001) Coronaviral infections. In: Williams ES, Barker IK (eds) Infectious diseases of wild mammals. Iowa State University Press, Ames, pp 245-253

49. O'Brien SJ, Troyer JL, Brown MA, Johnson WE, Antunes A, Roelke ME, Pecon-Slattery J (2012) Emerging viruses in the felidae: shifting paradigms. Viruses 4:236-257

50. Mochizuki M, Akuzawa M, Nagatomo H (1990) Serological survey of the Iriomote cat (Felis iriomotensis) in Japan. J Wildl Dis 26:236-245

51. Chiang P-J, Lin L-K, Yuan S-L (2015) Assessment of the Critical Habitat of Leopard Cat (Prionailurus bengalensis) (1/2). Taipei, Taiwan, p 89

52. Matter HC, Daniels TJ (2000) Dog ecology and population biology. In: Macpherson CNL, Meslin FX, Wandeler AI (eds) Dogs, zoonoses and public health. CAB International, Wallingford, pp $17-62$

53. Sepúlveda M, Pelican K, Cross P, Eguren A, Singer R (2015) Fine-scale movements of rural free-ranging dogs in conservation areas in the temperate rainforest of the coastal range of southern Chile. Mamm Biol 80:290-297

54. Blanchong JA, Robinson SJ, Samuel MD, Foster JT (2016) Application of genetics and genomics to wildlife epidemiology. J Wildl Manag 80:593-608
55. Chiang S-Y, Wu H-Y, Chiou M-T, Chang M-C, Lin C-N (2016) Identification of a novel canine parvovirus type $2 \mathrm{c}$ in Taiwan. Virol J 13:160

56. Chapman MS, Rossmann MG (1993) Structure, sequence, and function correlations among parvoviruses. Virology 194:491-508

57. Laurenson K, Sillero-Zubiri C, Thompson H, Shiferaw F, Thirgood S, Malcolm J (1998) Disease as a threat to endangered species: Ethiopian wolves, domestic dogs and canine pathogens. Anim Conserv 1:273-280

58. Miyazawa T, Ikeda Y, Maeda K, Horimoto T, Tohya Y, Mochizuki M, Vu D, Vu GD, Cu DX, Ono K (1998) Seroepidemiological survey of feline retrovirus infections in domestic and leopard cats in northern Vietnam in 1997. J Vet Med Sci 60:1273-1275

59. Nishimura Y, Goto Y, Yoneda K, Endo Y, Mizuno T, Hamachi M, Maruyama H, Kinoshita H, Koga S, Komori M (1999) Interspecies transmission of feline immunodeficiency virus from the domestic cat to the Tsushima cat (Felis bengalensis euptilura) in the wild. J Virol 73:7916-7921

60. Munson L, Terio KA, Ryser-Degiorgis M-P, Lane EP, Courchamp F (2010) Wild felid diseases: conservation implications and management strategies. In: Macdonald DW, Loveridge AJ (eds) Biology and conservation of wild felids. Oxford University Press, New York, pp 237-259

61. Deem SL, Spelman LH, Yates RA, Montali RJ (2000) Canine distemper in terrestrial carnivores: a review. J Zoo Wildl Med 31:441-451

62. Ikeda Y, Nakamura K, Miyazawa T, Chen M-C, Kuo T-F, Lin JA, Mikami T, Kai C, Takahashi E (2001) Seroprevalence of canine distemper virus in cats. Clin Diagn Lab Immunol 8:641-644

63. Pei CJ-C (2011) Study on the disease and conservation medicine of the endangered leopard cat. Council of Agriculture, Executive Yuan, Taipei, Taiwan, p 26

64. Truyen U (2006) Evolution of canine parvovirus - a need for new vaccines? Vet Microbiol 117:9-13

Publisher's Note Springer Nature remains neutral with regard to jurisdictional claims in published maps and institutional affiliations. 